九州大学学術情報リポジトリ

Kyushu University Institutional Repository

\title{
On a new species and a new record of alpheid shrimps from Japan
}

Miyake, Sadayoshi

Zoological Laboratory, Department of Agriculture, Kyushu University

Miya, Yasuhiko

Zoological Laboratory, Department of Agriculture, Kyushu University

https://doi.org/10.5109/22751

出版情報：九州大学大学院農学研究院紀要. 14 (1)，pp.133-141，1966-06. Kyushu University バージョン：

権利関係 : 
Journal of the Faculty of Agriculture, Kyushu University, Vol. 14, No. 1 June 30,1966

On a new species and a new record of alpheid shrimps from Japan*

Sadayoshi Mryake and Yasuhiko Mrya

Up till now few genera of the family Alpheidae, i.e. Alpheus, Synalpheus, Athanas and Betaeus, have been recorded from Japan. Recently we were unexpectedly able to find two species, each belonging to Salmoneus and Automate. The former species, Salmoneus babai sp. nov., is collected from a coral reef of Amami-oshima, the Ryukyu Islands. The latter species from Shikano-shima, Fukuoka Pref. and Amakusa, the northwestern part of Kyushu may be referable to Automate gardineri Coutière and is perhaps new to the fauna of Japan.

All the specimens are deposited in the collection of the Zoological Laboratory, Faculty of Agriculture, Kyushu University. We wish to express our hearty thanks to Dr. Taiji Kikuchi of the Amakusa Marine Biological Laboratory, Kyushu University and Mr. Keiji Baba of our laboratory, for their kindness to offer us the material.

\section{Salmoneus babai sp. nov.}

(Fig. 1)

Diagnosis. Rostrum cutlass-shaped, equilaterally triangular in dorsal view, with a short obscure median carina; tip reaching middle of third antennular segment. Scaphocerite exceeding antennular peduncle. Movable finger in large cheliped crescent, much longer than immovable one; upper margin of palm slightly convex, without any longitudinal concavity; proximal portion of palm deeply notched at lower side.

Description of holotype. The rostrum is cutlass-shaped, equilaterally triangular in dorsal view and provided with a short obscure median carina; the tip of it reaches the middle of the third antennular peduncle (Fig. 1, A, B).

The eye is dorsally and laterally concealed by the orbital hood

* Contributions from the Zoological Laboratory, Faculty of Agriculture, Kyushu University, No. 347 . 
produced into an acute triangular tooth; the orbitorostral margin has a right angle.

At the level of the base of the antennule the carapace is provided with a weak line which extends as far backward as the anterior half of it. The pterygostomial margin is rounded.

The antennular segments are short and broad; the stylocerite is broad and pointed, and reaches the end of the second segment, which is as long as broad, and longer than the visible portion of the first, while as long as the third. The undivided part of the outer flagellum consists of three joints; the free part of the shorter ramus is divided into four joints covered with short hairs.

The antennal peduncle hardly reaches the end of the third segment of the antennular peduncle, and bears three teeth on the heavy basicerite, i.e. a prominent inferior, a smaller superior and a rounded lateral one; the carpocerite bears a short spine on the outer distal margin; the scaphocerite is twice as long as broad; it exceeds the antennular peduncle, while the lateral spine of it is small and fails to reach as far forward as the lamella.

The first legs are distinctly unequal, and are folded beneath the body; each of the palms turns outward at a right angle (Fig. 1, C, E); the larger (right) exceeds the end of the antennular peduncle with the distal portion of the merus. The movable finger is crescent, much longer than the immovable finger and about half as long as the palm (Fig. 1, D); both of the fingers are sharp pointed, and strongly compressed; the cutting edge of each finger is provided with four exactly fitting teeth. The palm is slightly compressed, being higher than thick, and has the superior margin somewhat convex; the proximal portion of the palm is deeply notched at the inferior margin. The carpus is short, cup-shaped, being less than a third as long as the palm; the merus is slightly shorter than the palm, slender, straight on the dorsal margin, and somewhat concaves on the ventral margin which curves towards the carpus and the palm; the ischium is also slender, and somewhat shorter than a half of the merus.

The small cheliped is slender, less than half as long as the larger one, and has toothless fingers (Fig. 1, E).

In the second leg the carpus is subdivided into five joints, the proximal of which is slightly shorter than the total length of the following four joints (Fig. 1, F).

The last three legs resemble each other in shape, and have the simple dactylus (Fig. 1, G, H); in the third and the fourth legs the propodus is as long as the merus, but in the fifth that is 1.4 times of its merus. The propodus of the third leg bears eight spines on the ventral margin and a pair of spines on the ventral distal 
corner; the carpus bears one spine on the same distal portion; the merus is about three times as long as broad; the ischium provided
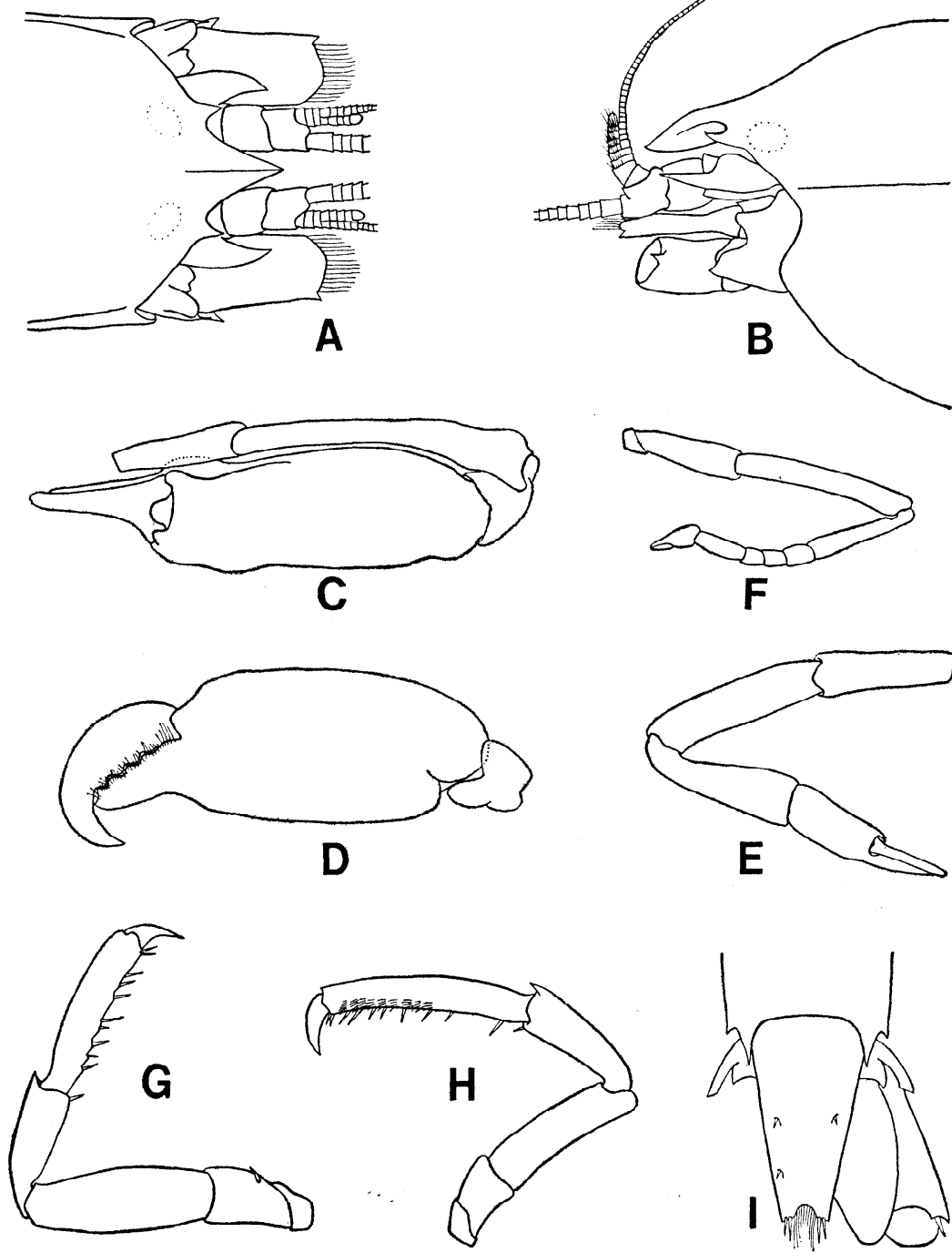

Fig. 1. Salmoncus babai sp. nov., holotype, ovig. ㅇ․

A : anterior part of body in dorsal view, $x 9, \quad B$ : anterior part of body in lateral view, $\times 9, \quad \mathrm{C}$ : large cheliped in lateral view, $\times 9, \quad \mathrm{D}:$ movable finger, chela and carpus of large cheliped in ventral view, $9, \mathrm{E}$ : small cheliped in lateral view, $\times 15, \mathrm{~F}$ : second leg, $\times 9, \mathrm{G}$ : third leg, $\times 9, \mathrm{H}$ : fifth leg, 9 , I : telson and right uropod in dorsal view, $\times 9$. 
with a movable spine on the proximal half of the ventral margin is three-fifths of the merus. In the fifth leg the ventral margin of the propodus is provided with ten spines and transverse rows of hairs in the distal part; the carpus bears one spine on the ventral distal corner; the ventral margin of the ischium is unarmed.

The posterior margins of the pleura of the first three abdominal segments are broadly rounded, while those of the following two are pointed; in the sixth abdominal segment the posterior margin of the pleuron is also pointed, and the posterolateral angles of tergum end in a sharp point.

The telson is tapering, 4.6 times as long as the posterior brcadth and slightly shorter than the uropod (Fig. 1, I); the posterior margin has a median concavity furnished with five pairs of plumose setae; either side of this concavity bears two spines, the inner being somewhat longer than the outer.

The colour in life is uniformly bright yellow.

Dimensions (in $\mathrm{mm}$ ).

$\begin{array}{lrr}\text { Total length } & 20.6 & 10.6 \\ \text { Carapace length including rostrum } & 7.7 & 4.0 \\ \text { Telson, } & 2.3 & \\ \quad \text { length } & 0.5 & 0.3 \\ \text { breadth of posterior margin } & & \\ \text { Large cheliped, } & 3.7 & 2.0 \\ \quad \text { length of palm } & 1.8 & 1.1 \\ \text { height (breadth) of palm } & 1.3 & 1.0 \\ \text { thickness of palm } & 1.6 & 1.1 \\ \text { length of movable finger } & 3.0 & 2.0 \\ \text { length of merus } & 0.7 & 0.3 \\ \text { breadth of merus } & & \\ \text { Third leg, } & 2.0 & 1.2 \\ \text { length of propodus } & 2.1 & 1.3 \\ \text { length of merus } & 0.8 & 0.3\end{array}$

Types. Holotype, ovigerous female, Zoological Laboratory, Faculty of Agriculture, Kyushu University (ZLKU), Cat. No. 3246, Suno coral reef, Kasari, Amami-oshima, July 31, 1965, K. Baba leg. Paratype, 1 male, ZLKU, Cat. No. 3247, the same data as in the holotype.

Remarks. Salmoneus babai sp. nov. is most closely related to Salmoneus sibogae (De Man, 1910), S. serratidigitus (Coutière, 1896) and S. mauiensis (Edmondson, 1930). The principal characters separating the present species from the above three are based on the nature of 
the palm of the large cheliped: in this species the superior margin of the palm is not furnished with any longitudinal groove and the proximal portion of the palm is deeply notched at the lower side, whereas in $S$. sibogae and $S$. serratidigitus the palm has both longitudinal groove and deep notch, and further in S. mauiensis the palm is entire, without any groove and notch.

And also the present species is closely related to $S$. hilarulus (De Man, 1910), which was lacking in both of the chelipeds. The present species, however, is distinguished from that species with the cutlassshaped rostrum and the longer scaphocerite.

According to Mr. Baba's information the colour in life of type specimens is uniformly bright yellow and it resembles $S$. serratidigitus, which Coutière (1897, p. 234) describes as: "Couleur d'un beau jaune uniforme, ......"

\section{Automate gardineri Coutière, 1902}

(Fig. 2)

Automate Gardineri Coutière, 1902, p. 337-Minikoi Island, Laccadive Islands; Madhu Vahri, Goidu and Hulule Atolls, Maldive Islands; Muscat; Djibouti; Kingsmill Island [= Gilbert Islands].

Automate Gardineri: Coutière, 1905, p. 854, figs. 127, 128-No new locality.

Automate jolınsoni Chace, 1955, p. 13, fig. 7-Bikini and Eniwetok Atolls, Marshall Islands.

Automate johnsoni: Banner, 1956, p. 321-Saipan Island, Mariana Islands.

Automatc gardincri: Holthuis, 1958, p. 17, fig. 6-Eylath, Israel; Red Sea.

Automate gardineri: Banner and Banner, 1964, p. 85-Canton Island, Phoenix Islands.

Description. The rostrum in dorsal view is rounded or triangular; the tip of it curves downward and fails to reach as far forward as the anterior margin of the carapace (Fig. 2, A, B); the pterygostomial margin is rounded.

The visible portion of the first antennular segment is 1.5 times as long as the eye peduncle, and is half to three-fourths of the second; the stylocerite reaches the end of the first segment; the second is twice to three times as long as the third, and varies from 2.4 to 4.3 times as long as broad at the maximum portion; the thickend part of the outer antennular flagellum consists of eight to fourteen joints.

The carpocerite slightly passes over the antennular peduncle; in the large specimens the tip of the scaphocerite reaches two-thirds of the second antennular segment; in the smaller specimens it reaches the end of the second segment. 
The third maxilliped exceeds the antennular peduncle by about the length of the ultimate segment which is eight times as long as broad and armed with numerous paired short spines on the superior margin; the penultimate is 2.4 times as long as broad; the antepenultimate is swollen, being 4.2 times as long as broad (Fig. 2, C).

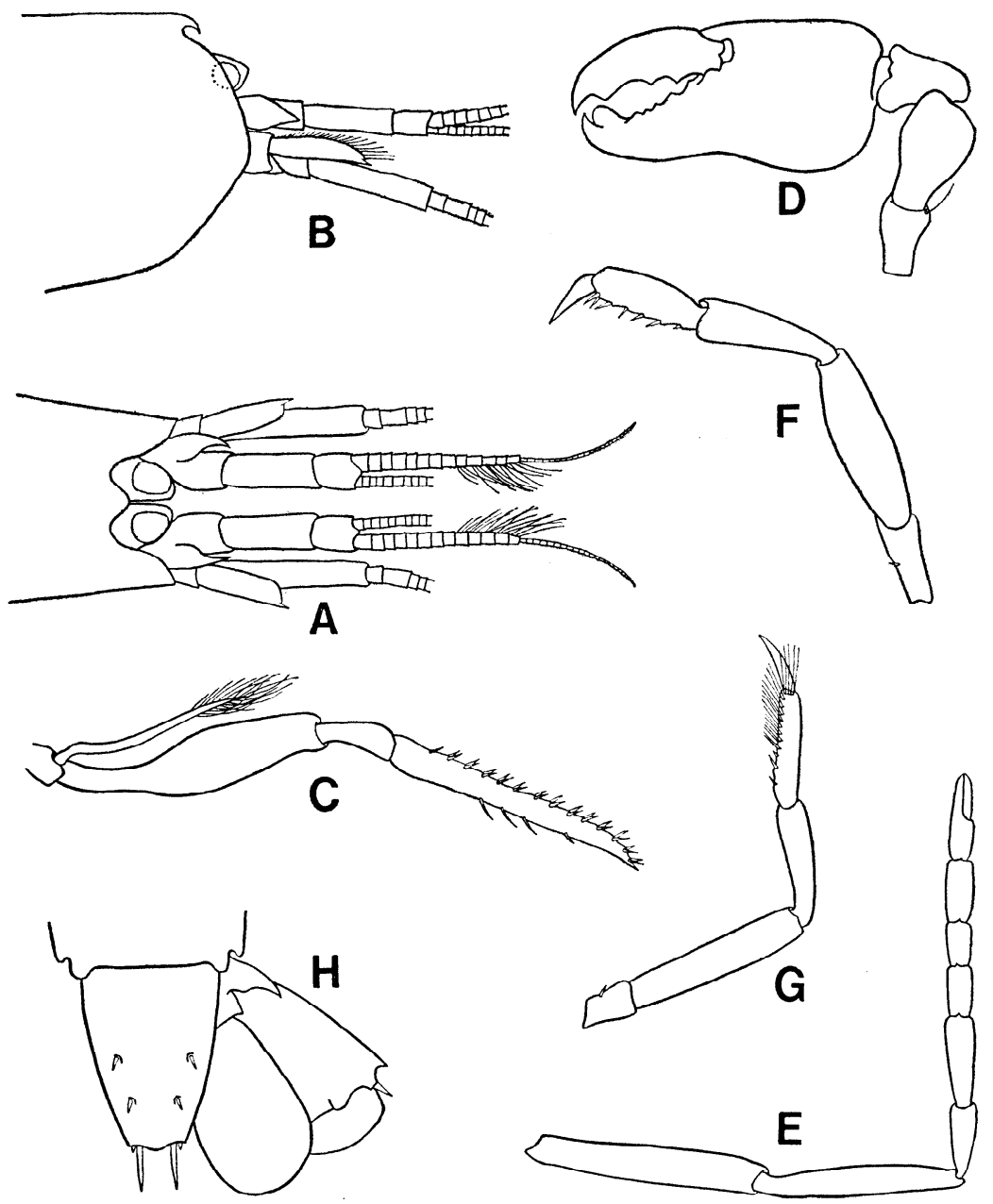

Fig. 2. Automate gardineri Coutière, 1902.

A : anterior part of body in dorsal view, $x 10, \quad B$ : anterior part of body in lateral view, $\times 10, \quad \mathrm{C}$ : third maxilliped, $\times 10, \mathrm{D}:$ large cheliped in lateral view, $>5, \quad \mathrm{E}$ : second leg, $\times 10, \mathrm{~F}$ : third leg, $\times 10, \mathrm{G}$ : fifth leg, $\times 10, \mathrm{H}$ : telson and right uropod in dorsal view, $\times 9$. 
In the large cheliped the cutting edge of the immovable finger bears a strong tooth near the apex; the tooth is separated by a distinct interval from three small teeth in the medial portion, and two larger teeth on the proximal third of the cutting edge (Fig. 2, D); these three teeth are placed more externally than that distal tooth and those proximal teeth. The movable finger has a single distal and two smaller proximal teeth on the cutting edge, being as long as the palm. The ischium bears a small spine or a seta on the dorsal distal corner.

In the second leg the first two joints of the carpus show a ratio of $1: 1.25-2.0$ (Fig. 2, E).*

The last three legs have several spines on the ventral margin of the propodus and a spine on the ventral margin of the ischium (Fig. $2, F, G)$.

The telson is 1.3 times as long as broad at the base (Fig. 2, H); it bears two pairs of dorsal spines, i.e. the anterior pair is placed on the middle of the telson and the posterior lies on the distal fourth; the posterior margin is broadly convex, bears two pairs of distal spines; the outer one is very small, the inner is as long as the breadth of the posterior margin.

The largest ovigerous female measures $19.2 \mathrm{~mm}$ from the tip of the rostrum to the posterior margin of the telson.

Colour. These specimens are pale orange when alive, with red chromatophores distributed over the entire body. The lateral side of the carapace is dark orange. In the large cheliped the movable finger and margins of chela are tinged with light yellowish orange, the carpus is dark orange. Eggs are dark orange.

Habitat. These shrimps from Shikano-shima were obtained under stones of the gravelly sandy beach in the tidal zone, where in most cases Alpheus bisincisus De Haan were found.

Material examined. 1 \&, ZLKU, Cat. No. 2452, Katsuma, Shikanoshima, Fukuoka Pref., June 11, 1965, K. Baba leg. 1 ovig. 우, 2 우우, 2 juv., ZLKU, Cat. No. 3132, Katsuma, Shikano-shima, Fukuoka Pref., July 13, 1965, Y. Miya leg. 1 ㅇ, ZLKU, Cat. No. 3403, off Uze, Tomioka, Amakusa, $70 \mathrm{~m}$ in depth, Apr. 16, 1964, T. Kikuchi leg.

Remarks. Chace (1955) and Banner (1956) pointed out the possibility that $A$. johnsoni was identical with A.gardineri. Afterwards Holthuis (1958) supported this opinion after the examination of specimens from the Red Sea, and stated that Automate sp. described by De Man (1911) might be referred to A. gardineri.

* The relative length of the first two carpal joints in the second leg is expressed as a ratio based on the length of the first joint. 


\section{Characters}

Rostrum

Second antennular

segment,

length/breadth

Stylocerite

Scaphocerite
A. (ardineri $^{1)}$

rounded, with
lateral grooves

$4.0^{3}$

reaching end of 1st antennular segment

passing over middle of 2 nd antennular segment

A. johnsoni ${ }^{2)}$

Present material

triangular, without lateral grooves

2.5

overreaching end of 1st segment

reaching nearly or quite to distal fifth of 2 nd segment rounded or triangular, without lateral grooves

$2.4-4.3$

reaching end of 1st segment

extending from two-thirds to end of 2nd segment

1) Coutière (1905).

2) Chace (1955).

3) Measured by the Coutière's figures, and he states, "L'article médian, de longueur variable avec l'âge des spécimens, ......"

As a result of the examination of the present material (seven specimens, $9.2-19.2 \mathrm{~mm}$ in total length), it seems advisable to follow the Holthuis' opinion because the small differences between $A$. gardineri and $A$. johnsoni enumerated by Chace prove to fall within the range of variations (shown in the above table).

\section{References}

Banner, A. H., 1953. The Crangonidae, or snapping shrimp, of Hawaii. Pacific Sci., vol. 7 , no. 1 , pp. $3-147$, figs. $1-50$.

Banner, A. H., 1956. Contributions to the knowledge of the alpheid shrimp of the Pacific Ocean. Part 1. Collections from the Mariana Archipelago. Pacific Sci., vol. 10, no. 3, pp. 318-373, figs. 1-23.

Banner, A. H., 1959. Contributions to the knowledge of the alpheid shrimp of the Pacific Ocean. Part 4. Various small collections from the Central Pacific area, including supplementary notes on alpheids from Hawaii. Pacific Sci., vol. 13, no. 2, pp. 130-155, figs. 1-13.

Banner, A. H. and D. M. Banner, 1964. Contributions to the knowledge of the alpheid shrimp of the Pacific Ocean. Part 9. Collections from the Phoenix and Line Islands. Pacific Sci., vol. 18, no. 1, pp. 83-100, figs. 1-5.

Chace, F. A., Jr., 1955. Notes on shrimps from the Marshall Islands. Proc. U. S. Nat. Mus., vol. 105 , pp. 1-22, figs. 1-8.

Coutière, H., 1896. Note sur quelques genres nouveaux ou peu connus d'Alphéidés formant la sous-famille des Alphéopsidés. Bull. Mus. Hist. nat. Paris, vol. 2, no. 8, pp. 380-386.

Coutière, H., 1897. Note sur quelques alphéidés nouveaux ou peu connus rapportés de Djibouti (Afrique orientale). Bull. Mus. Hist. nat. Paris, vol. 3, no. 6, pp. 233236 . 
Coutière, H., 1899. Les "Alpheidae," morphologie externe et interne, formes larvaires, bionomie. Ann. Sci. nat. Zool., ser. 8, vol. 9, pp. 1-559, figs. 1-409, pls. 1-6, 1 map.

Coutière, H., 1902. Sur quelques espèces nouvelles du genre Automate de Man. Bull. Mus. Hist. nat. Paris, vol. 8, no. 5, pp. 337-342.

Coutière, H., 1905. Les Alpheidae. In: J. S. Gardiner, The Fauna and Geography of the Maldive and Laccadive Archipelagoes. vol. 2, pt. 4, pp. 852-921, figs. 127-139, pls. $70-87$.

Holthuis, L. B., 1958. Contributions to the knowledge of the Red Sea. no. 8. Crustacea Decapoda from the northern Red Sea (Gulf of Aqaba and Sinai Peninsula). I. Macrura. Sea Fisheries Res. Sta., Haifa, Israel. Bull. no. 17, pp. 1-40, figs. 1-15.

Man, J. G. De, 1911. The Decapoda of the Siboga Expedition. Part 2. Family Alpheidae. Siboga Exped., Monogr. 39a ${ }^{1}$, pp. 133-465.

Man, J. G. De, 1915. The Decapoda of the Siboga Expedition. Supplement to Part 2. Family Alpheidae. Explanation of plates of Alpheidae. Siboga Exped., Monogr. $39 \mathrm{a}^{1}$, pls. 1-23. 